\title{
ANALISIS STRATEGI PENGHIMPUNAN DANA ZAKAT LEMBAGA AMIL ZAKAT NASIONAL BAITUL MAAL HIDAYATULLAH (LAZNAS BMH)
}

\author{
Abdul Wahid Mongkito \\ IAIN Kendari \\ wahid.raha88@gmail.com
}

\begin{abstract}
,
Referring to a study conducted by the National Amil Zakat Agency BAZNAS in cooperation with the Bogor Agricultural University (IPB) in 2011, it was revealed that the potential of zakat Indonesia amounted to 217 trillion dollars and will continue to grow each year. But the magnitude of the potential can't be exploited by BAZ and LAZ were already there. Zakat manager need strategies to optimize zakat fundraising. Through the study of internal factors and external factors LAZNAS BMH organization, an analysis of Internal and External Factors Evaluation in order to obtain the right strategy to be done by the organization LAZNAS BMH although still common. Further research conducted by TOWS matrix to get some viable strategy undertaken by LAZNAS BMH, then choose the best strategy of the proper strategies conducted by LAZNAS BMH with Quantitative Strategy Planning Matrix (QSPM) analysis method, that is: to socialize so that Muslims are interested in LAZNAS BMH, expanding the scope of the zakat, as well as making zakat fund raising strategies and methods of the target receipt of zakat funds.
\end{abstract}

Keywords: Zakat, LAZNAS BMH, TOWS matrix, Quantitative Strategy Planning Matrix (QSPM) analysis method

\section{PENDAHULUAN / INTRODUCTION}

Islam merupakan sistem kehidupan yang bersifat komprehensif, yang mengatur semua aspek, baik dalam sosial ekonomi, politik maupun kehidupan yang spiritual. Zakat adalah ibadah maaliyah ijtima'iyyah yang memiliki posisi sangat penting, strategis dan menentukan, baik dilihat dari sisi ajaran Islam maupun dari sisi pembangunan kesejahteraan ummat (Qardawi, 1993). Zakat sebagai salah satu instrumen kebijakan fiskal dalam sistem ekonomi memiliki fungsi yang sangat strategis sebagai instrumen redistribusi kekayaan, sebagaimana yang terdapat dalam surat At-Taubah ayat 60

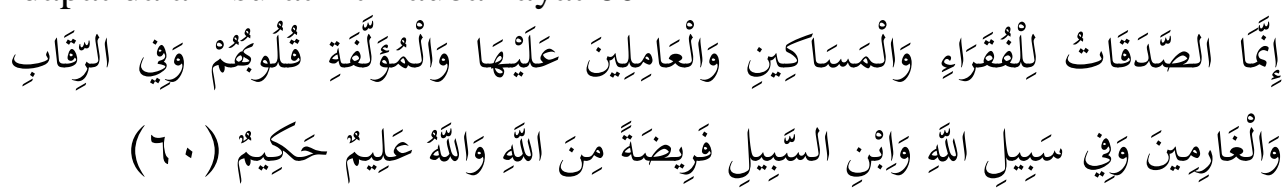

Sesungguhnya zakat-zakat itu, hanyalah untuk orang-orang fakir, orangorang miskin, pengurus-pengurus zakat, Para mu'allaf yang dibujuk hatinya, untuk (memerdekakan) budak, orang-orang yang berhutang, untuk jalan Allah dan untuk mereka yuang sedang dalam perjalanan, sebagai suatu ketetapan yang diwajibkan Allah, dan Allah Maha mengetahui lagi Maha Bijaksana. 
Beberapa studi telah mencoba mengkalkulasikan potensi zakat Indonesia secara nasional. Penelitian yang dilakukan Monzef Kahf (1989) misalnya, menyimpulkan bahwa potensi zakat nasional berada pada kisaran 1-2 persen dari total PDB. Sedangkan studi pusat bahasa dan budaya UIN Syarif Hidayatullah Jakarta (2005) menyatakan bahwa potensi zakat nasional pada kisaran 27,2 Triliun (Minarti, 2012).

Studi terbaru yang dilakukan oleh BAZNAS (Badan Amil Zakat Nasional) dan Fakultas Ekonomi dan Manajemen Institut Pertanian Bogor (FEM IPB) menunjukkan angka yang lebih besar. Menurut studi yang dilakukan pada tahun 2011 lalu terungkap bahwa potensi zakat nasional mencapai angka 3,4 persen dari PDB, atau tidak kurang dari Rp 217 Triliun (Minarti, 2012). Potensi ini diklasifikasi menjadi tiga, yaitu: pertama, potensi zakat rumah tangga secara nasional. Kedua, potensi zakat industri menengah dan besar nasional, serta zakat BUMN. Potensi yang dihitung pada kelompok yang kedua ini adalah zakat perusahaan dan bukan zakat direksi serta karyawan. Ketiga, potensi zakat tabungan secara nasional.

Kendati banyaknya BAZ maupun LAZ yang berkembang di Indonesia saat ini, namun penghimpunan zakat yang telah diperoleh masih sangat kecil jika dibandingkan dengan potensi zakat yang ada di Indonesia sehingga efek zakat yang diharapkan mampu mengentaskan kemiskinan masih jauh dari harapan. Menurut ketua BAZNAS, Didin Hafidhuddin, dana yang dapat dihimpun oleh Organisasi Pengelola Zakat (OPZ) pada tahun 2011 baru sebesar Rp. 1,7 triliun dan pada tahun 2012 penghimpunannya meningkat menjadi Rp 2,73 triliun atau sekitar satu persen dari potensi yang ada. Tahun 2015 Baznas Mencatat penerimaan Zakat sebesar 3,8 Triliyun, Tahun 2016 menjadi 5,12 Trilyun, Tahun 2017 kembali naik 20\% menjadi 6,24 Trilyun dan tahun 2018 menjadi 8,1 Triliyun

Sejak keluarnya ketiga aturan hukum positif yang mengatur tentang perzakatan di Indonesia, lembaga amil tumbuh bak cendawan di musim hujan, baik di tingkat pusat maupun daerah. Hingga kini setidaknya terdapat BAZNAS dan 18 LAZ tingkat nasional, 33 BAZ tingkat propinsi, dan $429 \mathrm{BAZ}$ tingkat kabupaten/kota. Belum lagi bila kita perhitungkan LAZ tingkat daerah, 4771 BAZ tingkat kecamatan, Unit Pengumpulan Zakat (UPZ) serta amil-amil tradisional individual berbasis masjid dan pesantren (Tim Penyusun, 2011).

Baitul Maal Hidayatullah misalnya sebagai Lembaga Amil Zakat yang tidak lepas dari induknya Ormas Hidayatullah. Lembaga Amil zakat yang resmi dikukuhkan menjadi Lembaga Amil Zakat Nasional pada tahun 2001 ini telah menggulirkan berbagai kegiatan sosial maupun pendidikan, dari menyantuni anak yatim, mendirikan pusat pembinaan anak sholeh dari kaum dhuafa, mendirikan lembaga pendidikan gratis hingga menyebarkan da'i ke pedalaman serta banyak lagi aktivitas ibadah sosial yang diretas.

Kendati telah memiliki 54 cabang, 12 rintisan cabang, lebih dari 200 jaringan, serta ribuan da'i yang tersebar diseluruh Indonesia namun dana zakat yang berhasil dihimpun dari masyarakat masih sangat rendah jika dibandingkan dengan potensi zakat yang ada di Indonesia. Sehingga menarik untuk diteliti bagaimana "Strategi Penghimpunan Dana Zakat Oleh Baitul Maal Hidayatullah (BMH)". Tujuan dari penelitian ini dilakukan untuk memformulasikan strategi dan kebijakan yang harus diterapkan LAZNAS BMH memperhatikan faktor-faktor internal dan eksternal serta batasan syariah sebagai bahan pertimbangan dalam meningkatkan jumlah penghimpunan dana zakat.

\section{TINJAUAN TEORITIK / LITERATURE REVIEW}

\section{A. Pengertian Zakat}

Ditinjau dari segi bahasa zakat merupakan bentuk kata dasar (masdar) dari zakka yang berarti berkah, tumbuh, bersih dan baik (Qardhawi, 1993). Zakat mengandung makna thaharah (bersih), pertumbuhan dan barakah. Dasar dari hal ini adalah firman Allah dalam surat At Taubah ayat 103 : 


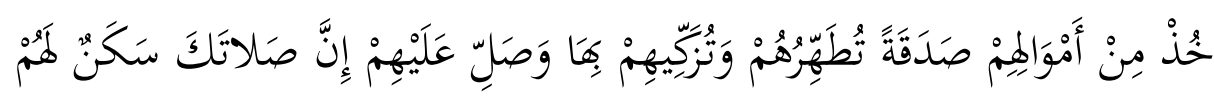

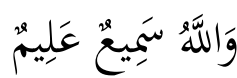

ambilah zakat dari sebahagian harta mereka yang dengan itu kamu membersihkan mereka dan mensucikan mereka, dan mendoalah untuk mereka. Sesungguhnya doa kamu itu menjadi ketenangan jiwa bagi mereka. Dan Allah maka mendengar lagi maha mengetahui.

Sedangkan makna pertumbuhan dan berkah diterangkan dalam surat Ar-Rum ayat 39

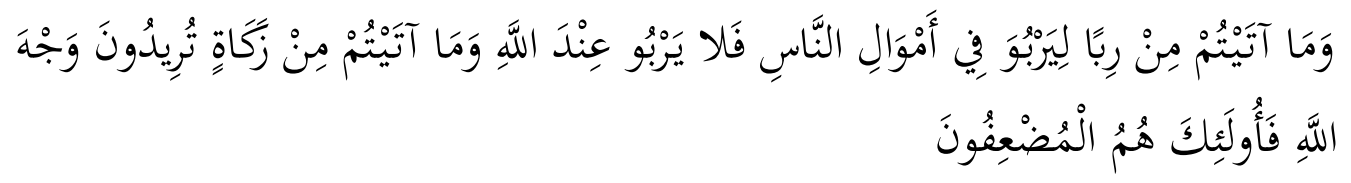

Dan sesuatu Riba (tambahan) yang kamu berikan agar Dia bertambah pada harta manusia, Maka Riba itu tidak menambah pada sisi Allah. dan apa yang kamu berikan berupa zakat yang kamu maksudkan untuk mencapai keridhaan Allah, Maka (yang berbuat demikian) Itulah orang-orang yang melipat gandakan (pahalanya).

Dan dikatakan, "zakaa az-zara'u-yazkuu-zakaatan" bilamana bertambah. Dan segala sesuatu bertambah, maka sesuatu tersebut "dikatakan" : zakaa. Zakat juga bermakna pujian sebagaimana firman Allah surat An Najm ayat 32 :

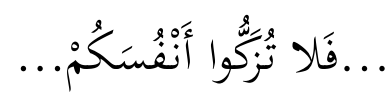

“....Maka janganlah kalian memuji diri kalian”.(Muhammad, 2011).

Sedangkan makna zakat secara syar'i adalah : "bagian tertentu dari harta yang tertentu, dibayarkan kepada orang tertentu yang berhak menerimanya sebagai ibadah dan ketaatan kepada Allah. Zakat juga bisa dimaknai sebagai pembersihan jiwa, harta dan masyarakat (Syahata, 2004).

B. Amil Zakat

Abdullah Nashih Ulwan menjelaskan bahwa yang dimaksud dengan amil zakat adalah orang-orang yang bekerja dalam bidang administrasi dan pengelolaan zakat baik mereka yang memungut zakat, penjaga gudang (bendahara), bagian keamanan, para sekretaris, akuntan dan distributor. masing-masing dari mereka mendapatkan gaji dari harta zakat (Nashih, 2008).

Secara hukum penarikan zakat baik secara langsung diserahkan dari muzakki kepada mustahiq pada dasarnya sah menurut syariah, namun penghimpunan zakat melalui lembaga amil memiliki beberapa keuntungan sebagaimana diungkapkan oleh Didin hafidhuddin pengelolaan zakat oleh lembaga pengelola zakat, apalagi yang mempunyai kekuatan hukum formal akan memiliki beberapa keuntungan :

Pertama, untuk menjamin kepastian dan disiplin pembayar zakat.

Kedua, untuk menjaga perasaan rendah diri para mustahiq zakat apabila berhadapan langsung untuk menerima zakat dari para muzakki.

Ketiga, untuk mencapai efisiensi dan efektifitas, serta dasar-dasar yang tepat dalam penggunaan harta zakat menurut skala perioritas yang ada pada suatu tempat.

Keempat, untuk memperlihatkan syiar islam dalam semangat penyelenggaraan pemerintahan yang islami" (Hafidhuddin, 2007).

Di Indonesia regulasi yang mengatur masalah zakat serta Lembaga pengelola zakat terdapat dalam Undang-Undang Nomor 23 Tahun 2011 tentang Pengelolaan Zakat. Badan amil zakat dan lembaga amil zakat mempunyai tugas pokok mengumpulkan, mendistribusikan, 
mendayagunakan zakat sesuai denagn ketentuan agama. Dalam melaksanakan tugasnya, badan amil zakat dan lembaga amil zakat bertanggung jawab kepada pemerintah sesuai dengan tingkatannya (Kholil, 2003).

Dalam UU nomor 23 Tahun 2011 tersebut dijelaskan bahwa pengelolaan zakat adalah kegiatan perencanaan, pelaksanaan, dan pengkoordinasian dalam pengumpulan, pendistribusian, dan pendayagunaan zakat. Undang-Undang ini juga mendefinisikan Badan Amil Zakat nasional (BAZNAS) dan Lembaga Amil Zakat (LAZ), Lembaga Amil Zakat adalah Lembaga yang berfungsi mengelola zakat, dibentuk oleh masyarakat, memiliki tugas membantu mengumpulkan mendistribusikan dan mendayagunakan zakat, dalam pembentukannya harus mendapat izin dari menteri atau pejabat yang ditunjuk oleh menteri, serta wajib melaporkan pelaksanaan pengumpulan, pendistribusian, pendayagunaan zakat yang telah diaudit kepada BAZNAS secara berkala.

\section{Strategi Penghimpunan Dana Zakat}

Pengelola zakat harus selalu ingat bahwa dalam mengelola dana zakat merupakan amanah yang harus benar-benar dijaga. Dalam pengelolaan zakat di Indonesia, diperlukan beberapa prinsip sebagai berikut :

1. Keterbukaan, untuk menumbuhkan kepercayaan masyarakat terhadap lembaga amil zakat, maka pihak pengelola zakat harus menerapkan manajemen yang terbuka. Pihak pengelola zakat harus menggunakan sistem informasi modern yang dapat diakses secara langsung oleh pihak-pihak yang memerlukan.

2. Menggunakan manajemen dan administrasi yang modern. Pengelola zakat tidak cukup hanya memiliki kemauan dan memahami hukum zakat, tetapi juga harus memahami manajemen dan administrasi modern. (Tim Penyusun, 2008)

3. Badan Amil Zakat dan Lembaga Amil Zakat harus mengelola zakat dengan sebaik-baiknya, sesuai dengan Undang-undang Nomor. 23 tahun 2011 dan Keputusan Menteri Agama RI, BAZ dan LAZ harus bersedia diaudit.

Dalam menghimpun suatu dana pastinya membutuhkan strategi yang jitu. Tidak hanya dalam berbisnis, menghimpun dana zakat juga memutuhkan strategi. Strategi yang digunakan dalam mengumpulkan dana zakat adalah:

1. Kampanye Media

Kampanye media adalah strategi yang dilakukan oleh suatu lembaga dalam rangka membangkitkan kepedulian masyarakat melalui berbagai bentuk publisitas pada media massa. Kampanye ini diarahkan kepada dua orientasi, yaitu yang pertama terbentuknya citra kondisi masyarakat yang kesulitan seperti contohnya penderitaan para korban bencana. Dan yang kedua adalah sosialisasi bahwa lembaga tersebut melakukan penghimpunan dana untuk membantu masyarakat yang kesulitan tersebut. Beberapa teknik yang dilakukan antara lain adalah:

a. Membuat Berita

Teknik ini dilakukan dengan cara membuat Press Release, undangan peliputan kegiatan, penyediaan kolom khusus informasi kegiatan, forum dialog atau diskusi dengan wartawan dan kunjungan ke media massa.

b. Memasang Iklan

Teknik ini dilakukan dengan cara memasang berbagai iklan di media massa, baik iklan yang berisi gambaran tentang kondisi masyarakat yang kesulitan, untuk membangkitkan kesadaran publik maupun iklan yang berisi informasi bahwa lembaga tersebut melakukan penghimpunan dana dan membantu masyarakat yang sedang mengalami kesulitan. Iklan yang dipilih bisa berbentuk advertorial atau display. 


\section{Direct Fundraising}

Direct fundraising adalah strategi yang dilakukan oleh lembaga dengan cara berinteraksi langsung dengan masyarakat, khususnya yang berpotensi menyumbangkan dananya. Strategi direct fundraising ini dilakukan dengan tujuan bisa mewujudkan donasi masyarakat seketika atau langsung setelah terjadinya proses interaksi tersebut. Teknik yang dapat dilakukan antara lain:

a. Direct Mail, yaitu teknik penggalangan dana yang dilakukan dengan cara mengirimkan surat kepada masyarakat calon donatur. Surat tersebut isinya adalah gambaran kondisi masyarakat yang akan dibantu atau program yang akan dilakukan, informasi tentang lembaga dan mekanisme yang bisa dilakukan masyarakat kalau hendak mendonasikan dananya. Misalnya penyebutan nomor rekening dan form kesediaan donasi yang harus diisi.

b. Telefundraising, yaitu teknik penggalangan dana yang dilakukan dengan cara melakukan kontak telepon kepada masyarakat calon donatur. Telepon ini umumnya dilakukan sebagai follow up dari surat yang telah dilakukan atau pertemuan yang pernah dilakukan.

c. Pertemuan Langsung, yaitu teknik penggalangan dana yang dilakukan dengan cara melakukan kontak secara langsung dengan masyarakat calon donatur. Selain berdialog langsung, maka pertemuan ini juga biasanya digunakan untuk membagikan brosur, leaflet atau barang cetakan lain guna mendukung keberhasilan penggalangan dana. Tidak sedikit pula pertemuan ini digunakan untuk menghimpun donasi secara langsung metode ini sering disebut denggan istilah door to door.

d. Kerjasama Program, yaitu strategi yang dilakukan oleh lembaga dengan cara bekerjasama dengan organisasi atau perusahaan pemilik dana. Dalam hal ini lembaga mengajukan proposal kegiatan kepada sebuah organisasi atau perusahaan. Proposal tersebut dipresentasikan di hadapan personil yang mewakili organisasi atau perusahaan. Dalam proposal tersebut harus termuat manfaat proposal bagi masyarakat yang dibantu, bagi organisasi atau perusahaan yang akan membiayai program dan bagi lembaga tersebut. Dalam proposal tersebut digambarkan sekilas hak dan kewajiban masingmasing pihak. Mekanisme bentuk donasi yang bisa dilakukan oleh organisasi atau perusahaan seperti bantuan langsung dari dana sosial yang sudah dianggarkan, penyisihan laba perusahaan atau dari potongan setiap transaksi belanja konsumen perusahan.

e. Fundraising Event, yaitu strategi yang dilakukan oleh lembaga dengan cara menyelenggarakan sebuah event untuk pengumpulan dana. Misalnya adalah malam amal, lelang lukisan, lelang busana tokoh terkenal, lelang karya tokoh, bentuk event lain yang digunakan untuk penggalangan dana.

f. Tebar Brozur, pamflet, buletin zakat, infak, dan sedekah.

3. Melakukan kerja sama dengan Bank dan membuka rekening zakat, infak, dan sedekah. Baik melalui layanan atm, sms-banking, maupun e-banking

4. Membentuk unit-unit Pengumpulan Zakat, sehingga masyarakat dengan mudah menyerahkan dana zakatnya.

5. Melakukan kerjasama dengan Ormas Islam, lembaga dakwah, dan majelis taklim untuk sosialisasi keberadaannya ditengah ummat (Tim Institut Manajemen Zakat, 2006).

D. Faktor-Faktor Kesuksesan Pengelola zakat

Kesuksesan penggalangan dana zakat harus diusahakan untuk jangka panjang. Manajemen dan administrasi harus modern dan profesional untuk mencapai tujuan organisasi 
pengelola zakat harus diperhatikan faktor-faktor internal maupun eksternal organisasi (Yani, 2011).

1. Faktor-Faktor Internal

Setiap Lembaga amil zakat memiliki kekuatan dan kelemahan pada organisasi masingmasing. Untuk mencapai visi dan misi amil zakat tersebut, kelemahan organisasi harus dirubah supaya menjadi lebih kuat dan kekuatannya harus dipertahankan. Berikut faktor-faktor internal yang mempengaruhi penghimpunan dana zakat sebuah lembaga zakat

a. Manajemen pengelola zakat

Hukum positif yang berlaku di Indonesia telah mengatur bawa lembaga pengelolaan zakat di Indonesia terdiri atas dua macam yaitu Badan Amil Badan Amil Zakat Nasional (BAZNAS) dan Lembaga Amil Zakat (LAZ) yang berfungsi membantu BAZNAS dalam pengelolaan zakat.

b. Pemasaran/Sosialisasi pengelola zakat

1. Sosialisasi pada Masyarakat

Ada banyak teknik yang dapat dilakukan untuk sosialisasi zakat. Pada dasarnya bisa dibagi menjadi dua bagian, yaitu bentuk atau cara-cara sosialisasi dan teknik atau cara-cara melayani transaksi (Minarti, 2011).

2. Distribusi zakat

Dalam bukunya Zakat Dalam Perekonomian Moderen, Prof. KH. Didin Hafidhuddin menjelaskan bahwa dana zakat harus disalurkan kepada tujuh ashnaf dengan menggabungkan kelompok fakir dan miskin sebagai satu kelompok. Beliau menjelaskan bahwa fakir dan miskin, dimana kedua kelompok ini memiliki perbedaan yang cukup signifikan, akan tetapi dalam teknis dan operasional sering dipersamakan, yaitu mereka yang tidak memiliki penghasilan sama sekali, atau memilikinya akan tetapi sangat tidak mencukupi kebutuhan pokok dirinya dan keluarga yang menjadi tanggungannya.

Beliau juga menjelaskan Kelompok Amil (petugas zakat), berhak mendapatkan bagian dari zakat, maksimal seperdelapan atau 12,5 persen dengan catatan bahwa petugas zakat ini memang melakukan tugas-tugas keamilan dengan sebaik-baiknya dan waktunya sebagian besar atau seluruhnya untuk tugas itu. Bagian untuk amil ini pun termasuk untuk biaya transportasi maupun biaya-biaya lain yang dibutuhkan untuk melaksanakan tugasnya (Hafidhuddin, 2008).

3. Keuangan / akuntansi

Menentukan kekuatan dan kelemahan keuangan organisasi sangat penting agar dapat merumuskan strategi secara efektif. Likuiditas, solvabilitas, modal kerja, surplus, pemanfaatan harta, arus kas dan modal saham dapat mengurangi sejumlah hal yang dapat dianggap feasible atau dapat dilaksanakan.

Pada pengelolaan dana zakat masyarakat terutama muzakki sangat menginginkan transparansi laporan keuangan pengelola zakat. Pengelola zakat mengumpulkan dana zakat masyarakat Islam, dan merupakan dana buat mustahik. Maka setiap pengelola zakat harus melakukan pelaporan penerimaan dana zakat dan penggunaannya secara terbuka dan transparan, artinya bahwa semua pengelola zakat yang menggunakan dana zakat dari para muzakki harus siap untuk membuka dirinya sehingga diketahui oleh masyarakat tentang pelaksanaan kegiatan dan penggunaan dananya. Pengelola zakat harus bersedia apabila masyarakat, muzakki ingin mengetahui kegiatan dan penggunaan dana zakat tersebut. Bahkan harus diaudit oleh auditor independen (Juwaini,2004).

4. Pelaksanaan program penyaluran zakat 
Dalam pengelolaan zakat penyaluran merupakan masalah terpenting dan utama. Hal ini dapat kita lihat dari sistematika penulisan al-Quran dimana perintah penyaluran Zakat (atTaubah: 60) lebih didahulukan dari ayat pengumpulan zakat (QS. At-Taubah: 103).

Dari sisi penyaluran, Undang-Undang tentang zakat yang baru menggunakan dua istilah, yaitu pendistribusian dan pendayagunaan. Pendayagunaan digunakan secara khusus sebagai istilah untuk penyaluran zakat secara produktif, dengan tujuan untuk meningkatkan kualitas ummat.

Penyaluran dana zakat dalam paradigma yang baru adalah penyaluran ke arah bentukbentuk yang produktif, tanpa meninggalkan bentuk konsumtif. Maksudnya, penyaluran dana zakat diperuntukkan juga bagi program jangka panjang dan program pemberdayaan (Tim Peneliti IMZ, 2012).

5. Penelitian dan pengembangan

Organisasi yang memiliki divisi lit-bang menghasilkan produk atau jasa yang unggul dan bisa memiliki keunggulan kompetitif . Lit-bang diarahkan pada pengembangan produk baru, memperbaiki mutu produk, atau memperbaiki proses kerja untuk mengurangi biaya. Litbang juga bersifat inovatif untuk lebih mengembangkan organisasi (Yani, 2008)

6. Pemanfaatan perkembangan teknologi informasi

LAZ-LAZ besar di Indonesia saat ini menjadi besar karena menggunakan infrastruktur IT yang memadai. Semakin canggih mereka menggunakan infrastrustuk teknologi informasi (IT), maka semakin efisien LAZ mengumpulkan dana dari para muzakki dan semakin mudah menyimpan data penerima zakat, data wilayah penerima zakat dan wilayah binaan lembaga zakat, data lembaga yang mendapat dukungan dari dana zakat, data wajib zakat, dan lain-lain (Minarti, 2008).

\section{Faktor Eksternal}

Setiap pengelola zakat memiliki peluang dan ancaman pada organisasi masing-masing. Untuk mencapai visi dan misi pengelola zakat ancaman pada organisasi tersebut harus dihindari agar organisasi tetap berjalan, serta memanfatkan setiap peluang yang ada untuk menghimpun dana zakat. Faktor-faktor eksternal yang harus diperhatikan oleh sebuah Lembaga Zakat adalah sebagai berikut :

a. Perluasan dalam kewajiban zakat

Dalam kitab-kitab para ulama harta yang menjadi objek zakat adalah sebagai berikut : Hewan ternak, emas dan perat, kekayaan dagang, pertanian, barang tambang, dan barang temuan. Dengan pendekatan ijmali, semua jenis harta yang belum ada contoh konkretnya di zaman Rasulullah saw, tetapi karena perkembangan ekonomi, menjadi benda yang bernilai, maka harus keluarkan zakatnya. Kriteria-kriteria yang digunakan untuk menetapkan sumber zakat dalam perekonomian modern adalah sebagai berikut :

1. Sumber zakat tersebut masih dianggap hal yang baru, sehingga belum mendapatkan pembahasan secara mendalam dan terinci. Berbagai macam kitab/iqh, terutama kitab fiqh terdahulu belum banyak membicarakannya, misalnya zakat profesi.

2. Sumber zakat tersebut merupakan ciri utama ekonomi modern, sehingga hampir di setiap negara yang sudah maju maupun negara berkembang, merupakan sumber zakat yang cukup potensial.

3. Sementara ini zakat selalu dikaitkan dengan kewajiban kepada perorangan, sehingga badan hukum yang melakukan kegiatan. usaha tidak dimasukkan ke dalam sumber zakat. Padahal zakat itu di samping harus dilihat dari sudut muzakki, juga harus dilihat dari sudut hartanya. Karenanya sumber zakat badan hukum perlu mendapat pembahasan, misalnya zakat perusahaan. 
4. Sumber zakat sektor modern yang mempunyai nilai sangat sangat signifikan yang terus berkembang dari waktu ke waktu dan perlu mendapatkan perhatian serta keputusan status zakatnya, seperti usaha tanaman anggrek, burung walet, ikan hias, dan lain sebagainya. Demikian pula sektor rumah tangga modern pada segolongan tertentu kaum muslimin yang berkecukupan, bahkan cenderung berlebih-lebihan, yang tercermin dari jumlah dan harga kendaraan serta aksesoris rumah tangga yang dimilikinya.

Berdasarkan kriteria-kriteria di atas, maka terpilihlah sumber zakat sebagai berikut: Zakat Profesi, Zakat Perusahaan, Zakat Surat-surat Berharga, Zakat Perdagangan Mata Uang, Zakat Hewan Ternak yang diperdagangkan, Zakat Madu dan Produk Hewani, Zakat Investasi Properti, Zakat Asuransi Syariah, Zakat tanaman anggrek, akat ikan hias, burung walet, dan sebagainya, Zakat aksesoris rumah tangga modern (Hafidhuddin, 2008)

b. Potensi Zakat di Indonesia

Studi terbaru yang dilakukan oleh BAZNAS (Badan Amil Zakat Nasional) dan Fakultas Ekonomi dan Manajemen Institut Pertanian Bogor (FEM IPB) menunjukan angka yang lebih besar. Menurut studi yang dilakukan pada tahun 2011 lalu terungkap bahwa potensi zakat nasional mencapai angka 3,4 persen dari PDB, atau tidak kurang dari Rp 217 Triliun (Minarti, 2011)

c. Kekuatan sosial, budaya, demografi dan lingkungan

Perubahan sosial, budaya, demografi, dan lingkungan berdampak besar terhadap hampir semua produk, jasa, pasar dan pelanggan. Organisasi besar maupun kecil dibuat bingung dan dihadapkan pada peluang dan ancaman yang timbul dari perubahan dalam variabel perubahan sosial, budaya, demografi, dan lingkungan.

Pada saat ini masyarakat muslim semakin banyak yang termotivasi melakukan kegiatan kedermawanan atau kepedulian salah satunya dengan cara berzakat, karena kesadaran bahwa perbuatan seperti itu diperintahkan atau dianjurkan oleh ajaran agama Islam.

Organisasi pengelola zakat yang kreatif dapat membangun kerja sama dengan pihakpihak perbankan, perkantoran, tempat ibadah untuk mendapatkan dan memperoleh dana zakat atau mendistribusi zakatnya tersebut. Mitra dalam pengumpulan zakat sangat diperlukan oleh pengelola zakat agar programnya berjalan dengan baik. Untuk mempermudah penghimpunan dana zakat, pengelola zakat melakukan kerja sama dengan pihak perbankan untuk menerima zakat dari para muzakki dan memberikan dana zakat bagi para mustahik atau pihak lain yang berhubungan. Selain perbankan, pihak unit usaha lain juga diperlukan, misalnya dari perkantoran pemerintah (untuk pegawai negri), perkantoran swasta, sekolah, dan yang lainnya. d. Kesadaran masyarakat yang semakin meningkat

Survei PIRAC melaporkan tingkat kesadaran muzakki meningkat dari 49,8\% di tahun 2004 menjadi 55\% di tahun 2007. Hal ini berarti dalam kurun waktu 3 tahun terjadi peningkatan sebesar 5,2\% kesadaran berzakat dalam masyarakat, jika 5,2\% itu dikalikan dengan populasi muzakki di Indonesia maka terdapat lebih dari 29 juta keluarga sejahtera yang akan menjadi warga sadar zakat. Sedangkan saat ini, diperkirakan hanya ada sekitar 12-13 juta muzakki yang membayar via LAZ, berarti masih ada lebih dari separuh potensi zakat yang belum tergarap oleh LAZ

e. Sinergitas OPZ

Mulai menjamurnya OPZ dapat menjadi sarana yang signifikan dalam memperkuat fungsi zakat dalam penghimpunan dan pendayagunaan dana zakat. Tapi, ada syarat mutlak yang harus dipenuhi, yaitu dengan melakukan sinergi. Sebab, tanpa hal itu, banyaknya OPZ hanya akan menimbulkan persaingan, kontradiksi dan konflik antar organisasi. Dan hal itu akan menjadi menyebabkan ketidakefektifan fungsi zakat baik dalam penghimpunan maupun dalam pendayagunaannya. (Minarti 2011). 


\section{f. Kekuatan teknologi.}

Perubahan dan penemuan teknologi revolusioner mempunyai dampak signifikan terhadap organisasi. Kemajuan teknologi dapat mempengaruhi produk, jasa, distribusi, pelanggan. Kemajuan teknologi dapat mengurangi atau menghilangkan hambatan biaya, rangkaian produksi menjadi lebih pendek. Kemajuan teknologi dapat menciptakan keunggulan kompetitif. Kemajuan teknologi dapat yang lebih berdaya guna ketimbang keunggulan yang sudah ada.(Yani, 2008)

\section{Manajemen Strategis}

Dalam bahasa Arab, manajemen diwakili oleh kata ( نظّ ) yang berarti mengatur, menyusun, mengorganisir; menyesuaikan, mengontrol; menyiapkan, mempersiapkan; merencanakan.

Menurut Muhammad Abdul Jawwad, manajemen adalah:

Aktivitas menertibkan, mengatur, dan berpikir yang dilakukan oleh seseorang, sehingga dia mampu mengurutkan, menata, dan merapikan halhal yang ada di sekitarnya, mengetahui prioritas-prioritasnya, serta menjadikan hidupnya selalu selaras dan serasi dengan yang lainnya.(Abdul, 2004)

Organisasi adalah sekumpulan orang yang memiliki tujuan yang sama dan sepakat bekerjasama untuk mencapai tujuan-tujuan yang ditetapkan. Dari definisi tersebut, karakteristik sebuah organisasi adalah berisi orang-orang yang sepakat terhadap tujuan, dan ada pembagian tugas yang tercermin dalam sebuah struktur.(Hubeis, 2008). Untuk mencapai setiap tujuan organisasi maka diperlukan strategi yang jitu, kemudian strategi - strategi tersebut dikelola dengan baik oleh setiap orang-orang yang ada di dalam organisasi tersebut sesuai dengan tugasnya masing-masing.

Setiap pakar mendefinisikan strategi secara berbeda-beda, namun pada intinya adalah sama. Seperti yang dijelaskan pada makna stategi Lawrence R. Jauch dan William F. Glueck (1998) mendefinisikan strategi adalah :

"a strategi Is inified, comprehensive, and integrated plan that the relates the strategic advantages of the firm to the challenges of the environment and that is designed to ensure that the basic objektive of the enterprise are achieved through proper execution by the organization

Dengan demikian strategi menurut mereka adalah :

Sebuah rencana yang disatukan, luas dan terintegrasi dan menghubungkan keunggullan perusahaan dengan tantangan lingkungan serta dirancang untuk memastikan tujuan utama perusahaan dapat dicapai melalui pelaksanaan yang tepat oleh organisasi.(Yogi, 2007)

J. david Hunger \& Thomas L. Wheelen mendefinisikan Managemen strategis adalah serangkaian keputusan atau tindakan manajerial yang menentukan kinerja perusahaan dalam jangka panjang. Manajemen strategis meliputi pengamatan lingkungan, perumusan strategi (perencanaan jangka panjang), implementasi strategis, dan evaluasi serta pengendalian. Manajemen strategis menekankan pada pengamatan dan evaluasi peluang dan ancaman lingkungan dengan melihat kekuatan dan kelemahan perusahaan (david, 2003). 
Pada pembuatan strategi organisasi dibutuhkan data yang terdapat dalam organisasi tersebut, dan membuat analisis internal pada organisasi dan analisis eksternal yang mempengaruhi organisasi tersebut. Hal yang dilakukan adalah

- Dengan melihat visi dan misi

- Lingkungan tempat organisasi itu beroperasi

- Konsumen organisasi tersebut

- Peraturan dalam pelaksanaa oraganisasi tersebut.

Melakukan analisis eksternal diperlukan faktor-faktor :

- Strength (kekuatan)

- Weakness (kelemahan)

Melakukan analisis eksternal, diperlukan faktor-faktor :

- Opportunity (peluang)

- Threat (ancaman) (Yani, 2008)

E. Strategi Matriks Internal-Eksternal (I-E)

Matriks IE didasarkan pada dua dimensi kunci : total nilai IFE yang diberi bobot pada sumbu-x dengan total nilai EFE yang diberi bobot pada sumbu-y. Perlu diingat bahwa setiap divisi dari organisasi harus menyusun matriks IFE dan matriks EFE untuk bagian dari organisasi tersebut. Dari total nilai yang dibobot dari setiap divisi, dapat disusun matriks IE pada tingkat korporasi. Pada sumbu-x matriks IE, total nilai IFE yang dibobot dari 1,0 sampai 1,99 menunjukan posisi internal yang lemah, nilai 2,0-2,99 dianggap sedang. Sedangkan nilai 3,0-4,0 dianggap kuat. Demikian pula dengan sumbu-y, total nilai EFE yang diberi bobot 1,01,99 dianggap lemah, nilai 2,0-2,99 dianggap sedang, sedangkan 3,0-4,0 dianggap tinggi.

Matriks I-E dapat dibagi menjadi tiga bagian utama yang mempunyai dampak strategis berbeda :

Pertama, divisi yang masuk kedalam sel I, II, atau IV dapat disebut tumbuh dan membangun. Strategi intensif (penetrasi pasar, pengembangan pasar, atau pengembangan produk) atau integratif (integrasi ke belakang, integrasi ke depan, integrasi horizontal) mungkin paling tepat untuk divisi-divisi tersebut.

Kedua, divisi yang masuk kedalam sel III, V, dan VII, paling baik dikelola dengan strategi pertahankan dan pelihara, strategi penetrasi pasar dan pengembangan produk merupakan dua strategi yang umum digunakan untuk jenis-jenis divisi ini.

Ketiga, divisi yang masuk ke dalam sel VI, VIII, atau IX paling baik dikelola dengan strategi panen atau divestasi, organisasi-organisasi yang sukses adalah yang berhasil mencapai portofolio di atau sekitar sel I dalam matriks IE.

\section{F. Strategi Matriks Threats-Opertunities-Weaknesses-Strengths (TOWS)}

Pada tahap analisis ini perumusan perencanaan strategi ini adalah dengan menggunakan matriks TOWS. TOWS merupakan perangkat pencocokan yang penting yang membantu manajer mengembangkan empat tipe strategi : strategi SO, WO, ST dan WT.

Tujuan dari matriks TOWS ini adalah menghasilkan alternatif strategi yang layak, bukan untuk memilih strategi mana yang terbaik. Sebab, tidak semua strategi yang dikembangkan dalam matriks TOWS akan dipilih untuk diterapkan.

Dalam penelitian ini, analisis TOWS ini digunakan untuk mengidentifikasi berbagai faktor secara sistematis sehingga dapat memaksimalkan kekuatan (Strengths) dan peluang (Opportunities), secara bersamaan juga dapat meminimalkan kelemahan (Weaknesses) dan ancaman (Threats) yang dihadapi LAZNAS BMH, khususnya dalam melakukan perencanaan kedepan. Ada empat tipe strategi yang dapat dikembangkan dengan menggunakan analisis 
TOWS: SO (Strengths-Opportunities), WO (Weaknesses-Opportunities), ST (StrengthsThreats), dan WT (Weaknesses- Threats).

\section{G. Strategi Quantitative Strategy Planning Matriks (QSPM)}

Hanya ada suatu teknis analitis dalam literatur yang dirancang untuk menentukan daya tarik relatif dari tindakan afternatif yang dapat dijalankan, teknik tersebut adalah Matriks Perencanaan Strategi Kuantitatif (QSPM) yang merupakan tahap 3 dari kerangka analitis perumusan strategi. Teknik tersebut secara objektif menunjukan strategi alternatif yang paling baik. QSPM menggunakan masukan dari analisis tahap satu dan hasil-hasil percocokan dari analisis tahap dua untuk memutuskan secara objektif strategi alternatif yang dapat dijalankan (R. David, 2004)

\section{METODE PENELITIAN / METHODS}

Jenis penelitian ini adalah deskriptif analisis, untuk melihat strategi-strategi yang diambil oleh manajemen LAZNAS BMH dalam menghimpun dana zakat lebih besar, agar visi dan misi pengelolaan zakat tersebut tercapai. Kemudian menganalisis dengan memperhatikan faktor-faktor internal dan eksternal serta batasan syariah sebagai bahan pertimbangan. Data yang akan digunakan dalam penelitian ini adalah data primer dan data sekunder. Data primer diperoleh melalui wawancara langsung kepada Pimpinan LAZNAS BMH dan departemen terkait, dan dibantu dengan instrumen kuisioner yang akan disiapkan. Data sekunder diperoleh dari setiap departemen terkait Laporan Keuangan, program penghimpunan, program pendayagunaan zakat, dan lain-lain

Penelitian ini diawali dengan menetukan faktor Internal-Eksternal kunci yang merupakan faktor yang berhubungan dengan penghimpunan dana zakat LAZNAS BMH, setelah itu dilakukan analisis faktor Internal-Eksternal dengan metode Analisis matriks IE untuk mengetahui strategi umum yang harus dilakukan. Setelah itu dilakukan penelitian lebih lanjut menggunakan metode kualitatif model SWOT (Strength, Weakness, Opportunity, Threat). Kemudian dilakukan analisis dengan mengunggunakan Matriks TOWS, dan keputusan strateginya yang lebih spesifik diperoleh melalui analisis matriks QSPM (Quantitative Strategy Planning Matrix).

\section{HASIL DAN PEMBAHASAN / DISCUSSION}

\section{A. Kondisi Internal LAZNAS BMH}

\section{Manajemen Pengelola Zakat}

Berdasarkan penelitian, manajemen LAZNAS BMH telah membentuk organisasi LAZ yang cukup baik, pengawasan pelaksanaan kerja dan hasil kerja, baik itu operasional maupun syariah dilakukan oleh Dewan Pengawas dan dewan pengawas pengawas syariah. Dewan pembina berfungsi Memberi pertimbangan, fatwa, saran, dan rekomendasi kepada badan pelaksana. Begitu pun dengan pendapatan pegawai yang sudah cukup karena diatas Upah Minimum Regional UMR wilayah masing-masing cabang. Namun, Perumusan strategi belum maksimal dilakukan oleh LAZNAS BMH serta masih adanya tumpang tindih tugas dan fungsi disebabkan karena personil yang masih kurang

2. Pemasaran Pengelola Zakat

a. LAZNAS BMH senantiasa mensosialisasikan tentang kewajiban zakat secara umum melalui cabang LAZNAS BMH serta pondok pesantren Hidayatullah yang mengambil tugas BMH (jika belum ada BMH di Daerah tersebut). Melalui program-program pendayagunaa 
zakat yang telah dilakukan LAZNAS BMH secara tidak langsung memberi pemahaman kepada masyarakat akan pentingnya berzakat melalui amil zakat sehingga zakat tersebut dapat di fungsikan lebih efektif dan tepat sasaran,

b. LAZNAS BMH menjalin hubungan yang baik dengan harian umum nasional seperti seperti Harian Nasional seperti Republika, Suara Hidayatullah, TV swasta nasional, harian lokal, dan lebih khusus Majalah BMH yang terbit setiap bulan dengan produksi tidak kurang dari 50.000 eksamplar setiap terbit

c. LAZNAS BMH belum menjadi "Market Leader" pada penghimpunan dana zakat. LAZNAS BMH baru mengumpulkan dana zakat 9,5 Milyar rupiah ditahun 2009 serta meningkat menjadi 10,5 Milyar Rupiah pada tahun 2010. Jumlah ini masing di bawah dan BAZNAS dan LAZNAS lainnya yang sudah mencapai angka triliyunan rupiah dalam pengumpulan dana zakat.

3. Pelaksanaan Program Zakat

Pelaksanaan program zakat pada LAZNAS BMH diutamakan pada 7 (tujuh) asnaf zakat, yaitu, Amil, fakir Miskin, Sabilillah, Ibnu Sabil, Muallaf, Gharimin, Dari tujuh asnaf itu yang menjadi prioritas adalah Sabilillah melalui program andalannya "Dai membangun negeri", Walaupun ada pendapat sebagaian ulama bahwa zakat diprioritaskan untuk Fakir dan Miskin, Namun dalam hal Asnaf Sabilillah yang menjadi prioritas utama LAZNAS BMH dalam penelitian saya pada akhirnya bertujuan untuk kepentingan Fakir dan Miskin khususnya dalam penjagaan Aqidah serta kemampuan mereka bertahan hidup. Program pendidikan pun seperti itu, tujuan akhirnya adalah peningkatan pendidikan fakir dan miskin.

Program-program LAZNAS BMH telah disosialisasikan baik yang telah dilakukan maupun yang akan direncanakan melalui media-media yang ada secara berkala pada mediamedia partner LAZNAS BMH, dan secara rutin setiap bulan LAZNAS BMH menerbitkan buletin BMH yang khusus memuat program-program LAZNAS BMH, dan juga melalui situs www.bmh.or.id. Walaupun masih belum begitu maksimal karena masih banyak orang yang belum mengenal lembaga ini.

4. Memiliki Visi dan Misi Keumatan

Diawali dengan cita-cita ingin membangun peradaban Islam sejak didirikannya, LAZNAS BMH berkembang dengan visi dan misi keumatan yang meraka usung. Dengan visi "Menjadi lembaga amil zakat yang terdepan dan terpercaya dalam memberikan pelayanan kepada umat”. LAZNAS BMH menerapkan tiga Misi umum yaitu :

1. Meningkatkan kesadaran umat untuk peduli terhadap sesama

2. Mengangkat kaum lemah (dhuafa) dari kebodohan dan kemiskinan menuju kemuliaan dan kesejahteraan

3. Menyebarkan syiar Islam dalam mewujudkan peradaban islam

Visi dan Misi tersebut sangat menarik karena bersifat keumatan, namun menurut peneliti masih perlu ditambahkan target waktu dan intensitas dalam penjabarannya agar dapat dievaluasi secara berkala sehingga lebih konkret untuk di wujudkan.

5. SDM yang Berorientasi dakwah dan Profesional

Dalam perekrutan Karyawan di BMH, ada tiga sisi yang diterapkan oleh manajemen, yaitu skill, pendidikan, dan niatnya bergabung. Yang paling penting dari ke tiga indikator diatas adalah niatnya untuk bergabung pada LAZNAS ini. Dari 25 Karyawan yang bekerja di Jakarta, 9 orang berpendidikan SMU, 1 orang Diploma 3 (d3), 13 orang Strata satu (s1), serta 2 orang berpendidikna Strata dua (s2).

6. Transparansi Laporan Keuangan dan Laporan Program Zakat 
Laporan Keuangan LAZNAS BMH dan Laporan Program Zakat dapat diketahui oleh masyarakat melalui melalui harian nasional republika, Majalah BMH, dan media lainnya. Laporan keuangan dana zakat ini dilakukan secara terbuka dan transparan, yang berarti bahwa semua penggunaan dana zakat dari para muzakki harus siap untuk diketahui oleh masyarakat tentang pelaksanaan kegiatan dan penggunaan dananya. Laporan keuangan dia audit oleh auditor independen..

7. Pemanfaatan Perkembangan Teknologi Informasi

LAZNAS BMH mempunyai sistem informasi pada manajemen untuk memberikan informasi yang akurat, lengkap dan cepat akan mempengaruhi kualitas setiap pengambilan keputusan. Dengan adanya teknologi informasi dan komunikasi membuat aktivitas LAZNAS BMH menjadi semakin serba cepat, sehingga keputusan dapat diambil dalam waktu yang lebih singkat. Pimpinan LAZNAS BMH pusat dapat mengetahui kondisi aktivitas LAZNAS BMH cabang setiap hari. Teknologi ini pula dimanfatkan oleh LAZNAS BMH untuk melakukan pengumpulan, sosialisasi LAZNAS BMH, baik teknoloki Komunikasi maupun teknologi perbankan.

8. Kemandirian Pengambilan Keputusan (independen)

Sekalipun LAZNAS BMH berada di bawah naungan Ormas Hidayatullah namun pengambilan keputusan dan kebijakannya dilakukan secara mandiri. Dengan kemandirian yang dimiliki LAZNAS BMH terbebas dari berbagai kepentingan yang kadang merusak seperti kepentingan politik, pribadi dan lain-lain

9. Divisi Penelitian dan Pengembangan (Litbang)

LAZNAS BMH belum memiliki divisi khusus yang mengambil fungsi untuk melakukan penelitian dan pengembangan. Walaupun fungsi divisi ini sudah masuk dalam setiap departeman yang ada, namun belum efektif karena tidak secara fokus dilakukan.

10. Metode Penggalangan Dana

Metode penggalangan dana zakat yang dilakukan LAZNAS BMH masih belum maksimal, masih banyak cara yang dapat dilakukan untuk memaksimalkan penggalangan dana zakat masyarakat. Begitu pula dengan lingkup objek zakat yang di kelola.

11. Cabang dan Jaringan

LAZNAS BMH telah memiliki 54 Kantor Cabang, 12 Rintisan, serta ribuan da'i yang tersebar diseluruh Indonesia, 162 Unit penyaluran, serta lebih dari seribu lebih mitra kerja. Hanya saja LAZNAS BMH belum memiliki program yang baik dalam hal sosialisasi seta belum memiliki jaringan dari luar negeri dalam hal pengumpulan dana zakat, infaq dan sedekah.

\section{B. Kondisi Eksternal LAZNAS BMH}

1. Potensi Zakat yang Besar

Dalam sebuah penelitian yang dilakukan oleh BAZNAS bekerjasama dengan Institut Pertaanian Bogor di tahun 2011 terungkap Bahwa potensi Zakat di Indonesia sebesar 217 Triliyun rupiah dan akan terus meningkat setiap tahunnaya. Namun, potensi yang sebesar itu belum maksimal dikelola oleh lembaga Zakat, LAZNAS BMH sebagai Market leader penghimpunan dana Zakat hanya Mampu mengumpulkan total zakat 1,7 T pada tahun 2011, dan $2 \mathrm{~T}$ pada tahun 2012.

2. Masyarakat Semakin Sadar Berzakat melalui Amil

Meningkatnya Jumlah pengumpulan dana zakat yangg cukup signifikan yang dicapai oleh LAZ maupun BAZ tiap tahunnya menandakan kesadaran masyarakat untuk berzakat melalui LAZ atau BAZ semakin meningkat.

3. Banyaknya Penduduk miskin 
Data dari Badan Pusat Statistik tiga tahun terakhir, angka kemiskinan di Indonesia pada tahun 2016 mencapai 27,73 Juta jiwa, Tahun 2017 mencapai 26,56 juta jiwa, dan pada tahun 2018 tingkat kemiskinan menurun menjadi 25,95 Juta jiwa. Dengan menggunakan standar pendapatan perkapita $\$ 0,8$ per hari.

4. Adanya Organisasi Sejenis

Menjamurnya Lembaga Zakat baik yang profesional mau pun yang tidak di tanah air dapat menimbulkan ketidakpercayaan masyarakat terhadap LAZ maupun BAZ secara umum jika tidak dikelola secara profesional. LAZ ataupun BAZ yang ada juga akan bisa jadi menimbulkan persaingan siantara sesamanya karena memiliki objek yang sama.

5. Teknologi Semakin Berkembang

Perkembangan teknologi merupakan salah satu peluang untung mengumpulkan maupun mengelola Zakat dengan lebih baik. Dengan teknologi pula transparansi LAZ akan lebih mudah diakses dengan cepat. LAZNAS BMH senantiasa memanfaatkan teknologi dalam setiap aktifitasnya.

6. Perbankan ingin bekerjasama menjadi pengumpul Zakat

Perhatian perbankan terhadap dunia perzakatan perlu diapresiasi baik itu Bank syariah maupun Bank konvensional. Namun, sejauh yang kami amati LAZNAS BMH belum maksimal memenfaatkan peluang tersebut

7. Perusahaan Membuka Pintu untuk bekerja sama dalam Masalah Perzakatan

Di dalam Undang-Undang perzakatan Nomor 23 Tahun 2011 telah dijelaskan mengenai zakat profesi maupun zakat perusahan sehingga memberikam peluang bagi LAZ untuk membangun Kerjasama dengan Perusahaan tersebut. Atau pun LAZ dapat bekerja sama dalam bentuk program lain.

8. Pemerintah belum terlalu memperhatikan masalah zakat

Walaupun telah disahkan Undang-undang terbaru mengenai zakat, namun belum ada sanksi kepada individu ataupun perusahaan yang tidak membayar zakat. Selain itu kosentrasi pemerintah untuk membangun zakat masih sangat minim ketimbang perhatian terhadap pajak.

9. Korupsi Masih Banyak terjadi di Indonesia

Korupsi sudah menjadi pemberitaan yang hampir setiap hari kita temukan di media massa, sehingga seolah-olah tindakan buruk ini menjadi budaya dilingkup pemerintahan Indonesia. Bahkan salah satu kementrian yang paling banyak menggelapkan uang negara adalah kementrian agama. Hal ini kemudian menimbulkan ketidakpercayaan masyarakat terhadap suatu lembaga pengelola uang termasuk Lembaga Zakat.

10. Masyarakat Menginginkan Transparansi Program pengelolaan zakat dan Laporan

Keuangan

Zakat merupakan salah satu kewajiban umat Islam sehingga setiap Muzakki menginginkan harta zakatnya dikelola dengan baik, maka faktor ini bisa menjadi peluang sekaligus ancaman bagi lembaga zakat. LAZNAS BMH setiap tahunnya diaudit oleh akuntan publik, serta LAZNAS BMH juga selalu memanfaatkan media untuk mempublikasikan program-program zakat meraka.

\section{E.3. Hasil Pengolahan Data}

Melalui hasil penelitian atas faktor internal dan eksternal LAZNAS BMH diatas dilakukan evaluasi faktor internal eksternal maka diperoleh

\section{Tabel Matriks Internal Eksternal}

Total Rata-rata Tertimbang IFE

\begin{tabular}{|c|c|c|c|c|}
\hline \multirow[b]{2}{*}{ Total Rata-rata } & 4,0 & \multicolumn{2}{|c|}{3,0} & 2,0 \\
\hline & & I & II & III \\
\hline Tertimbang & & IV & $\mathrm{V}$ & VI \\
\hline EFE & 2,0 & & & \\
\hline
\end{tabular}




\section{Sumber : data sudah diolah,}

Hasil perhitungan dari Evaluasi Faktor Internal = 2,95

Hasil perhitungan dari Evaluasi Faktor Eksternal = 3.05

Maka pada Matriks IE berada pada sel II yang berarti tumbuh dan membangun. Pada sel II ini Strategi intensif (penetrasi pasar, pengembangan pasar, atau pengembangan produk) atau integratif (integrasi kebelakang, integrasi kedepan, integrasi horisontal). Untuk lebih lanjut mengenai Strategi intensif yang tepat dilakukan oleh LAZNAS BMH Hidayatullah dilakukan analisi Matriks TOWS

Pada tahap analisis ini terpilih strategi yang dianggap layak untuk diterapkan berdasarkan kekuatan, kelemahan serta peluang dan ancaman yang dimiliki oleh LAZNAS $\mathrm{BMH}$

Tabel Matriks TOWS

\begin{tabular}{|c|c|c|}
\hline & \begin{tabular}{|l} 
KEKUATAN (STRENGTH) \\
1. Memiliki Cabang dan Jaringan \\
yang cukup banyak \\
2. LAZNAS BMH senantiasa \\
mensosialisasikan tentang \\
kewajiban zakat \\
3. Memiliki Visi dan Misi \\
Keumatan \\
4. Publikasi pengelolaan zakat \\
(program yang telah dan akan \\
dilakukan) \\
5. SDM yang berorientasi \\
dakwah dan profesional \\
6. Transpransi laporan Keuangan
\end{tabular} & $\begin{array}{l}\text { KELEMAHAN (WEAKNESS) } \\
\text { 1.Belum memiliki perumusan } \\
\text { strategis dalam hal target } \\
\text { penghimpunan dana zakat } \\
\text { 2. Belum memiliki divisi } \\
\text { Litbang } \\
\text { 3.Metode penggalangan dana } \\
\text { yang masih kurang } \\
\text { 4.Belum menjadi Market Leader } \\
\text { dalam penghimpunan dana } \\
\text { zakat } \\
\text { 5.Objek harta zakat yang } \\
\text { dihimpun masih terbatas }\end{array}$ \\
\hline $\begin{array}{l}\text { PELUANG (OPPORTUNITY) } \\
\text { 1. Potensi Zakat yang Besar } \\
\text { 2. Masyarakat Semakin Sadar } \\
\text { Berzakat melalui Amil } \\
\text { 3. Banyaknya Penduduk miskin } \\
\text { dengan pemahaman agama } \\
\text { rendah } \\
\text { 4. Masyarakat Menginginkan } \\
\text { Transparansi Program dan } \\
\text { Laporan Keuangan } \\
\text { 5. Teknologi Semakin } \\
\text { Berkembang } \\
\text { 6. Perbankan \& Perusahaan ingin } \\
\text { bekerja sama }\end{array}$ & $\begin{array}{l}\text { STRATEGI S-O } \\
\text { - Melakukan perluasan } \\
\text { lingkup zakat }\left(S_{1}, O_{1,5}\right) \\
\text { - Membuat program } \\
\text { penyaluran dana zakat yang } \\
\text { menarik dan sesuai dengan } \\
\text { kebutuhan ummat yang } \\
\text { paling mendesak }\left(S_{3,5}, O_{4,5}\right) \\
\text { - Melakukan distribusi zakat } \\
\text { yang lebih intens pada } \\
\text { sabilillah }\left(S_{1,3,5}, O_{1,3}\right)\end{array}$ & $\begin{array}{l}\text { STRATEGI W-O } \\
\text { - Membuat strategi } \\
\text { penghimpunan dana zakat } \\
\text { dan metode target } \\
\text { penerimaan dana zakat } \\
\left(W_{1,5}, O_{1,3,6}\right) \\
\text { - Melakukan kerjasama } \\
\text { dengan pihak perbankan } \\
\text { dan Perusahaan }\left(W_{3,5}, O_{5,6}\right) \\
\text { - Membuat divisi khusus } \\
\text { Litbang }\left(W_{2,3,4}, O_{2,3}\right)\end{array}$ \\
\hline ANCAMAN (THREAT) & STRATEGI S - T & STRATEGI W-T \\
\hline
\end{tabular}


1. Adanya Organisasi Sejenis

2. Belum ada sanksi yang tegas dari pemerintah bagi muzakki yang tidak membayar zakat

3. Korupsi Masih Banyak terjadi di Indonesia

4. Kondisi perekonomian kurang stabil

5. Pemerintah menghapuskan LAZ
- Melakukan Sosialisasi sehingga umat Muslim tertarik pada LAZNAS $\operatorname{BMH}\left(S_{1,2,4}, T_{1,2}\right)$

- Melakukan transparansi laporan keuangan \& progran dngan lebih baik $\left(S_{5,6}, T_{3,5}\right)$
- Melakukan transformasi organisasi. $\left(W_{1,3}, T_{4,5}\right)$

- Bergabung dengan dengan lembaga zakat lain $\left(S_{1}, T_{5}\right)$

Sumber : Data sudah diolah

Selanjutnya di perolehstrategi terbaik yang harus diprioritaskan oleh LAZNAS BMH dalam memaksimalkan penghimpunan dana zakat dengan analisis QSPM.

Tabel Analisis Hasil Matriks QSPM

\begin{tabular}{|c|c|c|c|c|}
\hline No & Strategi & Internal & Eksternal & Total \\
\hline 1 & $\begin{array}{l}\text { STRATEGI S-O } \\
\text { - Melakukan perluasan lingkup zakat } \\
\text { - Membuat program penyaluran dana } \\
\text { zakat yang menarik dan sesuai } \\
\text { dengan kebutuhan ummat yang } \\
\text { paling mendesak } \\
\text { - Melakukan distribusi zakat yang } \\
\text { lebih intens pada sabilillah }\end{array}$ & 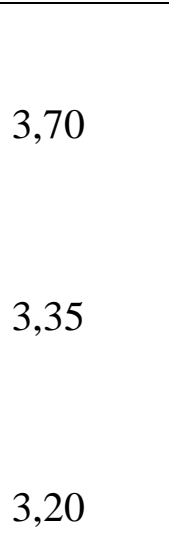 & 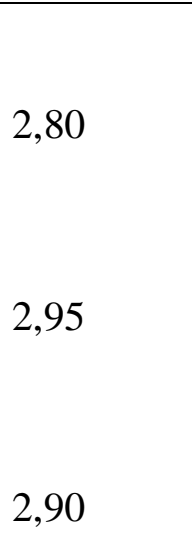 & 6,10 \\
\hline 2 & $\begin{array}{l}\text { STRATEGI W-O } \\
\text { - Membuat strategi penghimpunan } \\
\text { dana zakat dan metode target } \\
\text { penerimaan dana zakat } \\
\text { - Melakukan kerjasama dengan pihak } \\
\text { perbankan dan Perusahaan } \\
\text { - Membuat divisi khusus Litbang }\end{array}$ & 3,35 & 2,80 & 6,15 \\
\hline 3 & $\begin{array}{l}\text { STRATEGI S - T } \\
\text { - Melakukan Sosialisasi sehingga } \\
\text { umat Muslim tertarik pada } \\
\text { LAZNAS BMH }\end{array}$ & 3,50 & 3,25 & 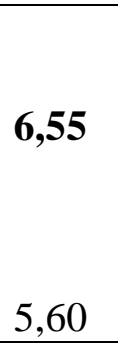 \\
\hline
\end{tabular}




\begin{tabular}{|l|l|l|l|l|}
\hline & $\begin{array}{l}\text { - Melakukan transparansi laporan } \\
\text { keuangan \& progran dngan lebih } \\
\text { baik }\end{array}$ & & & \\
\hline 4 & $\begin{array}{l}\text { STRATEGI W-T } \\
\text { - Melakukan Transformasi Organisasi } \\
\text { - Bergabung dengan dengan lembaga } \\
\text { zakat lain }\end{array}$ & 1,75 & 1,40 & 1,35 \\
\hline
\end{tabular}

Sumber : Data sudah diolah

Berdasarkan analisis hasil Matriks QSPM maka strategi yang diambil adalah strategi yang memiliki nilai paling tinggi, sehingga diperoleh strategi :

1. Melakukan Sosialisasi sehingga umat Muslim tertarik pada LAZNAS BMH

2. Melakukan perluasan lingkup zakat

Membuat strategi penghimpunan dana zakat dan metode target penerimaan dana zakat.

\section{KESIMPULAN / CONCLUSION}

Sebagai Kesimpulan penelitian ini adalah strategi yang terbaik yang harus dilakukan oleh LAZNAS BMH untuk meningkatkan penghimpunan dana zakatnya adalah sebagai berikut

1. Melakukan Sosialisasi sehingga umat Muslim tertarik pada LAZNAS BMH

2. Melakukan perluasan lingkup zakat

3. Membuat strategi penghimpunan dana zakat dan metode target penerimaan dana zakat Bentuk-bentuk Program kerja dari strategi diatas yang dapat dilakukan oleh LAZNAS BMH adalah sebagai berikut :

- Melakukan Sosialisasi sehingga umat Muslim tertarik pada LAZNAS BMH

1. Mengintruksikan kepada dai binaan Hidayatullah untuk senantiasa mengingatkan maupun menjelaskan tentang pentingnya berzakat melalui amil, khususnya LAZNAS BMH melalui mimbar-mimbar jum'an atau pun kajian pekanan paling minimal sekali dalam sebulan, dan terpenting di bulan Ramadhan.

2. Silaturahmi dengan perusahaan-perusahaan dan pejabat-pejabat serta para pengusaha dengan memperkenalkan program-program LAZNAS BMH..

3. Melakukan seminar-seminar bekerjasama dengan Lembaga keuangan syariah maupun perusahaan tertentu

- Melakukan perluasan lingkup zakat

Jenis-jenis harta zakat tersebut adalah : Zakat Profesi, Zakat Perusahaan, Zakat perusahaan online, Zakat Surat-surat Berharga, Zakat Perdagangan Mata Uang, Zakat Hewan Ternak yang diperdagangkan, Zakat Madu dan Produk Hewani, Zakat Investasi Properti, Zakat Asuransi Syariah, Zakat tanaman anggrek, zakat ikan hias, burung walet, dan sebagainya, Zakat aksesoris rumah tangga modern

- Membuat strategi penghimpunan dana zakat dan metode target penerimaan dana zakat

Strategi yang dapat dilakukan oleh LAZNAS BMH adalah :

Al-Kharaj: journal of Islamic Economic and Business Vol. 1 No. 1, Juni 2019 
1. Lebih menggiatkan Direct fundraising dengan memenfaatkan da'i dan pengurus LAZNAS BMH yang tersebar diseluruh Indonesia, mandatangi rumah-rumah Muzakki cukup efektif.

2. Membentuk unit-unit pengumpulan zakat sehingga masyarakat dengan mudah menyerahkan dana zakatnya.

Memanfatkan teknologi dengan menggunakan berbagai alat pembayaran digital seperti

Platform based dan Virtual Currency.

\section{DAFTAR PUSTAKA / REFERENCES}

Abdul, J. 2004. Menjadi Manajer Sukses. Jakarta: Gema Insani

David, H. J. \& Thomas, L. 2003. Manajeman strategis. Jogjakarta: Penerbit andi.

Hafidhuddin, D. 2008. Zakat dalam Perekonomian Moderen. Jakarta : Gema Insani.

Hubeis, M. 2008. Manajemen strategik dalam mengembangkan daya saing organisas., Jakarta: Elex Media Komputindo.

Juwaini, A. 2004, Berderma dan Berbagi, Jakarta : Teraju-Mizan.

Kholil, N. 2003. Hukum zakat dan pajak serta praktek pengelolaannya di Indonesia (tesis). Bogor : Progran Pascasarjana UIKA BOGOR.

Minarti, N. et. Al. 2011. Indonesia Zakat \& Development Report 2010:Menggagas Arsitektur Zakat Indonesia Menuju Sinergi Pemerintah dan Masyarakat Sipil Dalam Pengelolaan Zakat Nasional, Cet. 2 Jakarta: IMZ, , et al.2008. Zakat \& Empowering, Diskursus manajemen Zakat Antara Pemerintah dan Masyarakat.

, et al.2011. Indonesia zakat Devolpment Report 2012. Ciputat: Indonesia Magnificence of zakat.

Nashih, A.2008. Zakat menurut 4 mazhab. Jakarta : Pustaka Al kautsar.

Qardhawi, Y. 1993. Al-Ibadah fil-Islam. Beirut: Muassasah Risalah.

. 1993. Hukum Zakat Cetakan ketiga, Jakarta : Lintera Antar Nusa.

R. David, F. 2005. Stategic Management konsep Edisi 10, Jakarta: salemba empat, 2004 Manajemen Strategis. Konsep-konsep. (penerj: Kresno Saroso. Edisi 9. Jakarta. PT. Indeks.

Syahatah, H. 2004. Akuntansi zakat. Jakarta : Pustaka progresif.

Undang-Undang Republik Indonesia No. 23 Tahun 2011 Tentang Pengelolaan Zakat

Tim Institut Manajemen Zakat. 2006. Profil 7 Bazda Provinsi \& Kabupaten Potensial Di Indonesia, Ciputat: Intitut Manajemen Zakat.

Tim Penyusun. 2008. Panduan Organisasi Pengelolaan zakat, Jakarta:Departemen Agama RI,.

Yani, D. 2008, Strategi Penghimpunan Dana Zakat oleh Baznas, tesis magister pada Universitas Indonesia, Jakarta : tidak diterbitkan.

Yogi, widjana A. Ratnaningsih S. 2007. Manajemen strategi terapan, Jakarta: Poliyama widya Pustaka.

\section{Sumber Lain}

http://www.dakwatuna.com/2013/04/30/32350/strategi-LAZNAS

BMH-tingkatkanperolehan-zakat/, diakses 2 Apriil 2014 pukul 21.58

http://baznastanahdatar.or.id/program/13-estimasi-potensi-zakat-nasional.html, diakses pada 5 Juni 2013, pukul 15.00 WIB 
http://www.republika.co.id/berita/ekonomi/syariah-ekonomi/13/04/29/mm039y-potensizakat-rp-217-triliun-terserap-satu-persen, diakses pada Rabu, 5 Juni 2013, pukul 14:45 WIB

http://www.bmh.go.id.

http://www.bps.go.id.

Strategi Fundraising Zakat, http//:www.dompetdhuafa.com, diakses pada tanggal 31 Mei 2013 pukul. 20.28 WIB

Kamus al-Munawwir, Software Al-Munawwir Translator Program, v. 1.0.0, 2010 